\title{
Biracial study of arterial pressures in the first and second decades of life
}

\author{
O O AKINKUGBE, F M AKINKUGBE, O AYENI, H SOLOMON, K FRENCH, R MINEAR
}

British Medical fournal, 1977, 1, 1132-1134

\section{Summary}

The blood pressures of young Black and White American schoolchildren were measured and compared with those of Nigerian children of similar ages. Both diastolic and systolic pressures were consistently higher in the Nigerian children than in the Americans, both Black and White. The White children had the lowest pressures at each age. The mean weights and heights at each age were not significantly different in the three groups. Although the blood pressure of African children was higher than that of Black Americans, mean adult pressures are known to be similar in both groups. This suggests that the difference in childhood pressures must be due more to environmental factors than to genetic ones.

\section{Introduction}

It has been clearly established that mean arterial pressures in the Black population of the United States are higher than in their White counterparts. This striking difference seems to exist in practically all age groups from adolescence to old age. ${ }^{1-8}$ Most studies, however, have been silent about the pattern of blood pressure in the first decade of life in these communities. Yet if this racial difference is consistent it is important to determine how early in life it manifests itself and what factors (environmental or otherwise) cause it. The nature of essential hypertension may be more clearly understood if it could be studied very early in the course of its natural history. If environment has a major influence on the behaviour of arterial pressure in Black and White Americans then we would expect to find a different pattern in people of similar ages in West Africa (where most American blacks originally came from). We therefore studied arterial pressures in young Black and White American schoolchildren and in Nigerian schoolchildren.

\section{Subjects and methods}

We studied children aged 5-12 years from six state schools (three with predominantly White and three with predominantly Black children) in the Boston area. A similar group of schoolchildren at the

University of Ibadan, Nigeria

O O AKINKUGBE, MD, FRCP, professor of medicine (now principal, University College, Ilorin, Nigeria)

F M AKINKUGBE, $M B, M P H$, research fellow, institute of child health

O AYENI, BSC, PHD, senior lecturer, department of preventive and social medicine

Peter Bent Brigham Hospital, Harvard Medical School, Boston, Massachusetts, USA

H SOLOMON, MD, lecturer in medicine

K FRENCH, research assistant

Roxbury Comprehensive Community Health Centre, Boston University, Boston, Massachusetts, USA

$\mathrm{R}$ MINEAR, MD, lecturer in paediatrics
Abadina School, University of Ibadan campus, Nigeria, was also studied. They were aged 6-14 years.

In children aged under 12 blood pressure was measured with a standard mercury manometer using a cuff $9 \mathrm{~cm}$ wide. In children aged 12 years and over an adult cuff $(13 \times 25 \mathrm{~cm})$ was used. The recordings were made in each classroom with the children standing in a queue with an arm extended on a table. The diastolic pressure was taken as that at which muffling of sounds occurred (phase IV) and readings were recorded as the nearest $5 \mathrm{~mm}$ gradation below the observed figure. In all cases arterial pressures were measured between 0900 and 1600. Heights, weights, and arm circumference were also recorded.

\section{Results}

Altogether 2485 Nigerians (1399 boys and 1086 girls) and 1011 Americans were examined. Table I shows the racial distribution of children in the six Boston schools.

TABLE I-Distribution of racial groups in six schools in Boston

\begin{tabular}{l|c|c|c|c|c}
\hline & \multicolumn{2}{|c|}{ Blacks } & \multicolumn{2}{c|}{ Whites } & \multirow{2}{*}{ Total } \\
\cline { 2 - 3 } & Boys & Girls & Boys & Girls & \\
\hline St Joseph's & 48 & 43 & & & 91 \\
St Baker & 168 & 164 & 11 & 9 & 352 \\
Julie Ward Home & 15 & 20 & 38 & 49 & 35 \\
Mason & 8 & 11 & 38 & 106 \\
Emerson & 28 & 21 & 71 & 62 & 182 \\
James Motley & 26 & 19 & 102 & 98 & 245 \\
\hline \multicolumn{1}{c|}{ Total } & 293 & 278 & 222 & 218 & 1011 \\
\hline
\end{tabular}

In all three groups of schoolchildren (American Black, American White, and Nigerian) the systolic blood pressure advanced with age (fig 1). The mean systolic and disastolic pressures in the Nigerian

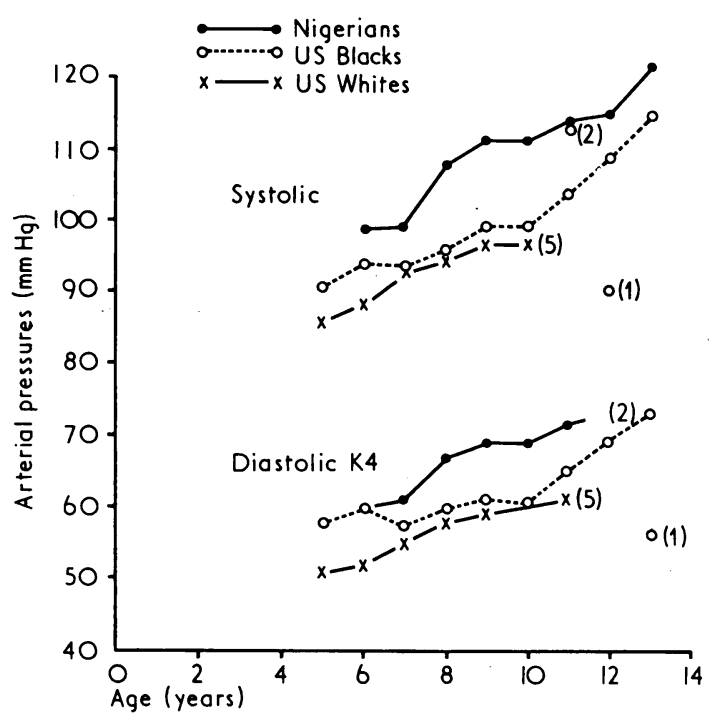

FIG 1-Mean arterial pressures of American Black and White schoolchildren and Nigerian children in 1975. Figures in parentheses indicate the small numbers of children aged 11 , 12 , and 13 years. 
TABLE II-Mean arterial pressures (mm Hg) of Black and White American children and Nigerian children in 1975. Numbers of children in each group are given in parentheses

\begin{tabular}{|c|c|c|c|c|c|c|c|c|c|c|c|c|}
\hline \multirow{4}{*}{$\underset{\text { (years) }}{\text { Age }}$} & \multicolumn{6}{|c|}{ Boys } & \multicolumn{6}{|c|}{ Girls } \\
\hline & \multicolumn{3}{|c|}{ Systolic } & \multicolumn{3}{|c|}{ Diastolic } & \multicolumn{3}{|c|}{ Systolic } & \multicolumn{3}{|c|}{ Diastolic } \\
\hline & \multicolumn{2}{|c|}{ American } & \multirow{2}{*}{ Nigerian } & \multicolumn{2}{|c|}{ American } & \multirow{2}{*}{ Nigerian } & \multicolumn{2}{|c|}{ American } & \multirow{2}{*}{ Nigerian } & \multicolumn{2}{|c|}{ American } & \multirow{2}{*}{ Nigerian } \\
\hline & Black & White & & Black & White & & Black & White & & Black & White & \\
\hline 5 & \multirow{10}{*}{ 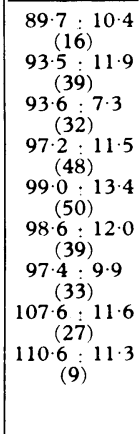 } & \multirow{8}{*}{$\begin{array}{c}84 \cdot 4: 8 \cdot 1 \\
(24) \\
87 \cdot 9: 7 \cdot 8 \\
(36) \\
93 \cdot 3: 8 \cdot 2 \\
(40) \\
94 \cdot 0.11 \cdot 5 \\
(47) \\
98 \cdot 1 \cdot 12 \cdot 2 \\
(43) \\
97 \cdot 7 \cdot 11 \cdot 3 \\
(26) \\
96 \cdot 0 \cdot 6 \cdot 5 \\
(5)\end{array}$} & \multirow{10}{*}{$\begin{array}{c}98 \cdot 7: 12 \cdot 3 \\
(288) \\
99 \cdot 0: 11 \cdot 8 \\
(216) \\
106 \cdot 0 \cdot 11 \cdot 7 \\
(179) \\
111 \cdot 2: 30 \cdot 6 \\
(208) \\
109 \cdot 1: 12 \cdot 0 \\
(227) \\
111 \cdot 0.13 \cdot 2 \\
(132) \\
110 \cdot 3.15 \cdot 2 \\
(94) \\
120 \cdot 0 \cdot 12 \cdot 2 \\
(31) \\
122 \cdot 2 \cdot 16 \cdot 9 \\
(18)\end{array}$} & $58 \cdot 1: 10 \cdot 3$ & $49 \cdot 0 \div 6 \cdot 8$ & \multirow{6}{*}{$\begin{array}{l}58 \cdot 5 \pm 7 \cdot 9 \\
59 \cdot 6 \pm 7 \cdot 5 \\
65 \cdot 6 \pm 9 \cdot 0 \\
68 \cdot 4 \pm 8 \cdot 8 \\
68 \cdot 4 \pm 9 \cdot 1\end{array}$} & \multirow{10}{*}{ 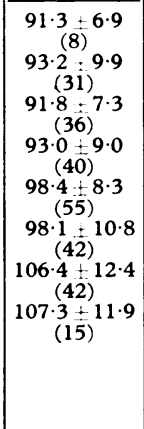 } & \multirow{7}{*}{$\begin{array}{c}86 \cdot 0+7 \cdot 8 \\
(24) \\
88 \cdot 2 \cdot 10 \cdot 0 \\
(25) \\
92 \cdot 2.8 \cdot 0 \\
(47) \\
94 \cdot 1 \pm 8 \cdot 1 \\
(37) \\
94 \cdot 8+9 \cdot 1 \\
(57) \\
94 \cdot 6+7 \cdot 9 \\
(26)\end{array}$} & \multirow{10}{*}{$\begin{array}{c}98.3+15 \cdot 4 \\
(240) \\
98 \cdot 7 \pm 11.5 \\
(176) \\
107.9 \pm 12.0 \\
(157) \\
109.5 \pm 11.3 \\
(150) \\
111.1 \pm 13.0 \\
(184) \\
116.0+12.6 \\
(122) \\
118.1 \pm 14.0 \\
(89) \\
120.9 \pm 11.7 \\
(22) \\
127.7+15.3 \\
(11)\end{array}$} & $56 \cdot 3 \pm 4 \cdot 4$ & $51 \cdot 5+4 \cdot 8$ & \multirow{10}{*}{$\begin{array}{l}59 \cdot 2 \pm 8 \cdot 7 \\
60 \cdot 6 \pm 8 \cdot 0 \\
66 \cdot 6 \pm 9 \cdot 1 \\
67 \cdot 2 \pm 8 \cdot 8 \\
68 \cdot 9 \pm 9 \cdot 6 \\
72 \cdot 0 \pm 8 \cdot 4 \\
73 \cdot 8 \pm 10 \cdot 8 \\
74 \cdot 1 \pm 9 \cdot 5 \\
83 \cdot 2 \pm 11 \cdot 1\end{array}$} \\
\hline 6 & & & & $59 \cdot 4: 10 \cdot 7$ & $51 \cdot 0: 6 \cdot 5$ & & & & & $59 \cdot 2 \pm 8 \cdot 0$ & $52 \cdot 0 \pm 6 \cdot 5$ & \\
\hline 7 & & & & $56 \cdot 3: 6.8$ & $54 \cdot 0: 5 \cdot 7$ & & & & & $58 \cdot 1 \pm 8 \cdot 0$ & $54 \cdot 4 \pm 6 \cdot 0$ & \\
\hline 8 & & & & $60 \cdot 0: 8 \cdot 4$ & $58 \cdot 0: 7 \cdot 9$ & & & & & $58 \cdot 8+7 \cdot 9$ & $56 \cdot 5 \pm 7 \cdot 1$ & \\
\hline 9 & & & & $61 \cdot 3: 9 \cdot 6$ & $59 \cdot 8 \div 8 \cdot 6$ & & & & & $60 \cdot 2 \pm 6 \cdot 5$ & $57 \cdot 5+7 \cdot 0$ & \\
\hline 10 & & & & $61 \cdot 2 \pm 9 \cdot 1$ & $59 \cdot 4 \div 8 \cdot 6$ & & & & & $58 \cdot 9 \pm 8 \cdot 6$ & $59 \cdot 0 \div 5 \cdot 7$ & \\
\hline 11 & & & & $59 \cdot 1: 6 \cdot 3$ & $60 \cdot 0: 6 \cdot 1$ & $70 \cdot 1+9 \cdot 2$ & & & & $68 \cdot 5 \div 8 \cdot 8$ & & \\
\hline 12 & & & & $66 \cdot 7: 7 \cdot 8$ & & $70 \cdot 1 \pm 11 \cdot 3$ & & $\left.\right|_{(2)} ^{112 \cdot 5+10 \cdot 6}$ & & $71 \cdot 3 \div 9 \cdot 7$ & $72 \cdot 5 \pm 3.5$ & \\
\hline 13 & & $90 \cdot 0: 0 \cdot 0$ & & $70 \cdot 0 \div 8 \cdot 3$ & $55 \cdot 0+0 \cdot 0$ & $78 \cdot 2 \pm 11 \cdot 2$ & & & & & & \\
\hline 14 & & & & & & $78 \cdot 3 \pm 9 \cdot 4$ & & & & & & \\
\hline
\end{tabular}

TABLE III-Mean arm circumference (cm) of Black and White Boston schoolchildren (boys and girls) in 1975. Numbers of children in each group are given in parentheses

\begin{tabular}{|c|c|c|c|c|c|c|c|c|c|}
\hline Age (years): & 5 & 6 & 7 & 8 & 9 & 10 & 11 & 12 & 13 \\
\hline $\begin{array}{l}\text { Black } \\
\text { White }\end{array}$ & $\begin{array}{c}16 \cdot 4: 1 \cdot 2 \\
(48) \\
17 \cdot 4: 1.6 \\
(24)\end{array}$ & $\begin{array}{c}16 \cdot 6: 1.4 \\
(6 \mathrm{i}) \\
17 \cdot 1 \cdot 1.7 \\
(70)\end{array}$ & $\begin{array}{c}16.7: 1.3 \\
(87) \\
17.5 \div 1.6 \\
(68)\end{array}$ & $\begin{array}{c}17 \cdot 7+2 \cdot 0 \\
(84) \\
18 \cdot 6+2 \cdot 1 \\
(88)\end{array}$ & $\begin{array}{c}18 \cdot 1+2 \cdot 1 \\
(100) \\
19 \cdot 1 \pm 2 \cdot 2 \\
(105)\end{array}$ & $\begin{array}{c}18 \cdot 7+2 \cdot 0 \\
(52) \\
19 \cdot 8+2 \cdot 1 \\
(81)\end{array}$ & $\begin{array}{c}19 \cdot 2+1 \cdot 7 \\
(5) \\
20 \cdot 1+2 \cdot 3 \\
(75)\end{array}$ & $\begin{array}{c}22 \cdot 3 \pm 1 \cdot 8 \\
(2) \\
21 \cdot 7 \pm 2 \cdot 5 \\
(42)\end{array}$ & $\begin{array}{c}20.0 \quad 0.0 \\
(1) \\
22.9 \pm 2.7 \\
(18)\end{array}$ \\
\hline
\end{tabular}

children were consistently higher than those of American Black and White children, this difference being most conspicuous between the ages of 7 and 10 years. Diastolic pressures seemed to follow the same trends as systolic pressures in each age group. American White children seemed to have the lowest mean pressures in every age division, and pressures in American Black children were somewhere between those in the White children and those in the Nigerians. A breakdown of the mean pressures according to sex showed a similar trend (table II).

Mean weights and heights were not significantly different in the three groups of schoolchildren or between sexes. Available data on arm circumference showed that American Black children had consistently higher mean values than American White children (table III).

\section{Discussion}

The major studies on arterial pressures in American children have focused on those over 4 years of age and they have uniformly alluded to the difficulties inherent in measuring blood pressures in infants and young children. ${ }^{7-10}$ In some studies 9- and 13-cm wide cuffs were used, depending on which more closely approximated to two-thirds of the arm, and cuff muffle was regarded as the diastolic marker. In others, a $12-\mathrm{cm}$ band was folded double to measure the pressure in children with very small arms. In a study carried out among English children ${ }^{11}$ the cuff was marked in $\mathrm{cm}$ so that it could be folded to a required measurement. The cuff was bound on to the arm so that at least half of it was covered; and the average width of the cuff was $4 \mathrm{~cm}$ for children under 2 years, $6 \mathrm{~cm}$ for those aged 2-4 years, and $8 \mathrm{~cm}$ for those aged 4-5 years. All these methods are at best approximate and have not been well correlated with intra-arterial pressure readings. Another non-invasive procedure using Doppler shifted ultrasound ${ }^{12}$ has been attempted in infants, but it is not clear to what extent the technique is generally applicable to surveys.

The mean systolic and diastolic arterial pressures were marginally but consistently higher in Black American children than in their White counterparts, but the difference in mean pressures between Nigerian children and American children (White and Black) was conspicuous. The cuffs and manometers used, most of the observers, and the circumstances of measurement were the same in both surveys. The observed differences could not be accounted for simply by body build, because the curves for heights and weights were almost identical in all three groups of schoolchildren. Mean arm circumferences in American Blacks, however, were marginally larger than in Whites.

Mean blood pressures in adult Negro populations in the

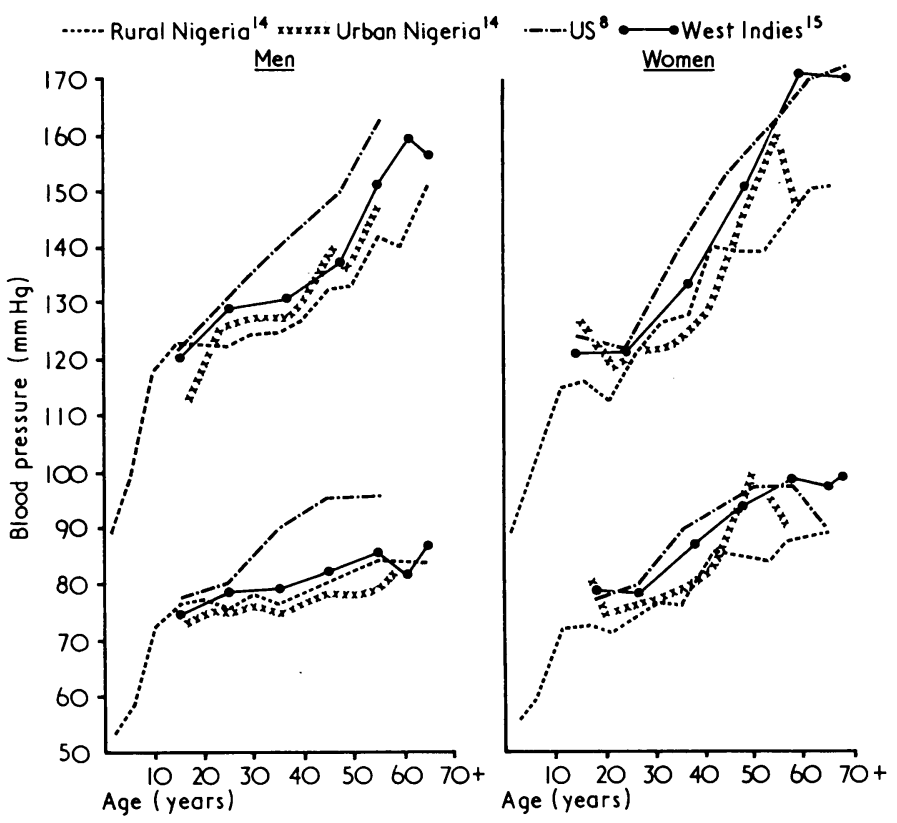

FIG 2-Mean systolic and diastolic pressures in Negro populations. 
United States, the Carribean, and Nigeria are shown in fig 2. In both men and women the mean systolic and diastolic pressures in American Negroes were slightly higher than those in West Indian or west African Negroes. Abrahams et al ${ }^{13}$ had earlier shown that blood pressures in indigenous west Africans were generally similar to those recorded in White populations in Europe and America.

If mean pressures in African children in Africa are significantly higher than those in children of African descent in the United States, and mean adult pressures are practically the same in both groups, then the sharp paediatric contrast must be attributable more to an environmental than to a genetic basis. We can only speculate on the factors that contribute to the rapid rise in blood pressure with age, which eventually causes the average American Black to end up with a considerably raised arterial pressure in subsequent decades of life. In this preliminary study we have found no evidence of a meeting point in arterial pressures, when the observed established differences in adolescence are taken back to the early part of the first decade in the form of a regression, but we did not study the behaviour of blood pressure in infancy and early childhood. This forms the subject of a separate study.

\section{References}

1 Adams, J M, American fournal of Medicine, 1932, 184, 342.

2 Rose, G, fournal of Chronic Diseases, 1962, 15, 373.

3 McDonough, J R, Garrison, G E, and Homes, C G, in The Epidemiology of Hypertension, ed J Stamler, R Stamler, and T N Pullman, p 167. New York, Grune and Stratton, 1962.

${ }^{4}$ Boyle, E, jun, et al, in The Epidemiology of Hypertension, ed J Stamler, R Stamler, and T N Pullman, p 193. New York, Grune and Stratton, 1967.

5 Wilber, J A, in The Epidemiology of Hypertension, ed J Stamler, R Stamler, and T N Pullman, p 439. New York, Grune and Stratton, 1962.

6 Hutcheson, J M, jun, Hejmancik, M R, and Herrman, G R, American Heart Fournal, 1953, 46, 565.

7 Graham, A W, Hines, E A, jun, and Gage, R P, American fournal of Diseases in Children, 1945, 69, 303.

${ }^{8}$ Comstock, G W, American fournal of Hygiene, 1957, 65, 271

${ }^{9}$ Londe, S, Clinical Pediatrics, 1966, 5, 71.

${ }^{10}$ Londe, S, Clinical Pediatrics, 1968, 7, 400.

11 Allen-Williams, G M, Archives of Disease in Childhood, 1945, 20, 125.

12 Janis, K M, Kemmerer, W T, and Hagood, C O, jun, Fournal of Pediatric Surgery, 1971, 6, 70.

13 Abrahams, D G, Alele, C O, and Barnard, B G, West African Medical Fournal, 1960, 9, 45.

${ }^{14}$ Akinkugbe, O O, and Ojo, O A, British Medical fournal, 1969, 2, 222

15 Miall, W E, et al, British Medical fournal, 1962, 2, 497.

(Accepted 15 February 1977)

\section{SHORT REPORTS}

\section{Water intoxication associated with carbamazepine treatment}

Carbamazepine has been reported to have an antidiuretic action, though it is not known how it produces this effect. We report a patient with water intoxication caused by carbamazepine treatment in whom the antidiuretic hormone 8-arginine vasopressin (AVP) was measured by a specific and sensitive radioimmunoassay."

\section{Case report}

A 45-year-old woman was admitted as an emergency to Leeds General Infirmary on 29 August 1976 because of poorly controlled epilepsy and increasing mental confusion. She had been an epileptic for many years. On admission she was taking phenytoin $100 \mathrm{mg}$ twice daily, phenobarbitone $30 \mathrm{mg}$ three times a day, carbamazepine $400 \mathrm{mg}$ three times a day, benzhexol $2 \mathrm{mg}$ three times a day, and folic acid $5 \mathrm{mg}$ three times a day. A course of erythromycin $500 \mathrm{mg}$ four times a day had been started for an infected lesion in her right great toe.

She was drowsy, disorientated, and dysarthric. There were no other abnormal neurological signs. In particular there was no evidence of raised intracranial pressure or head injury. The clinical picture was compatible with a postictal state or an overdose of anticonvulsant. There was no clinical evidence of fluid overload. Blood was taken for measuring urea and electrolytes. The serum sodium concentration was unexpectedly low (see table). We thought that this might be explained by inappropriate secretion of AVP caused by carbamazepine.

The dose of carbamazepine was reduced to $200 \mathrm{mg}$ three times a day and fluid intake restricted. The patient's clinical state improved greatly, plasma carbamazepine concentration fell, and serum electrolytes and osmolality returned to normal (see table). The change in treatment did not provoke further convulsions.

AVP was determined using a recently developed specific and sensitive radioimmunoassay. ${ }^{2}$ Plasma and urinary concentrations of the hormone were very high in the presence of toxic concentrations of carbamazepine, despite considerable plasma hypotonicity. When the dose of carbamazepine was reduced the plasma sodium and AVP concentrations returned to normal within three days, by which time plasma carbamazepine concentrations were within the accepted therapeutic range.

\section{Comment}

Carbamazepine has been thought to exert its antidiuretic effect either by potentiating the action of AVP on the renal tubules, ${ }^{3}$ or by
Blood values of drugs and plasma and urinary concentrations of AVP

\begin{tabular}{|c|c|c|c|}
\hline & 10 May 76 & 29 August 76 & 1 September 76 \\
\hline $\begin{array}{l}\text { Phenytoin } \\
\quad(\mu \mathrm{mol} / 1) \\
\text { Phenobarbitone } \\
\quad(\mu \mathrm{mol} / \mathrm{l}) \\
\text { Carbamazepine } \\
\quad(\mu \mathrm{mol} / \mathrm{l}) \\
\text { Plasma AVP } \\
\quad(\mathrm{ng} / \mathrm{l}) \\
\text { Urine AVP } \\
\quad \text { (ng/mmol creatinine) } \\
\text { Plasma sodium } \\
\quad \text { (mmol/1) } \\
\text { Plasma osmolality } \\
\text { (mmol/kg) } \\
\text { Urine osmolality } \\
\quad(\mathrm{mmol} / \mathrm{kg})\end{array}$ & $\begin{array}{c}31(100 \mathrm{mg} \\
\text { twice a day }) \\
110 \text { (30 mg } \\
\text { thrice daily) } \\
20(200 \mathrm{mg} \\
\text { thrice daily })\end{array}$ & $\begin{array}{c}20 \\
110 \\
63(400 \mathrm{mg} \\
\text { thrice daily }) \\
1 \cdot 7 \\
17 \\
120 \\
261 \\
375\end{array}$ & $\begin{array}{c}22 \\
72 \\
24(200 \mathrm{mg} \\
\text { thrice daily }) \\
0.33 \\
1 \cdot 7 \\
136 \\
274 \\
195\end{array}$ \\
\hline
\end{tabular}
Conversion: SI to traditional units-Phenytoin: $\mu \mathrm{mol} / 1 \approx 0.025 \mathrm{mg} 100 \mathrm{ml}$. Pheno-
barbitone $1 \mu \mathrm{mol} 1 \approx 0.023 \mathrm{mg} 100 \mathrm{ml}$. Carbamazepine $1 \mu \mathrm{mol} 1=0.024 \mathrm{mg} / 100 \mathrm{ml}$. Creatinine $1 \mu \mathrm{mol} / 1 \approx 0.0113 \mathrm{mg} / 100 \mathrm{ml}$. Sodium: $1 \mathrm{mmol} / 1=1 \mathrm{mEq}$. Osmolality: $1 \mathrm{mmol} / \mathrm{kg}=1 \mathrm{mOsm} / \mathrm{kg}$.

increasing AVP secretion from the pituitary. ${ }^{4}$ Attempts to measure AVP in patients treated with carbamazepine have produced conflicting results. To some extent this may reflect the great difficulty in measuring AVP in and below the normal range. Bioassay uses a difficult preparation - the water-loaded, alcohol-anaesthetised ratand is relatively insensitive. Most radioimmunoassays use antibodies of questionable specificity, but even a well-characterised assay, ${ }^{3}$ although providing evidence against a direct effect of carbamazepine on the pituitary, has not provided a conclusive answer.

Using a specific radioimmunoassay we showed high serum and urinary AVP levels when plasma carbamazepine concentrations were in the toxic range. This suggests a derangement of the osmotic control of AVP release from the pituitary, which is seen in physiological circumstances only with considerable hypervolaemia.

The administration of phenytoin and phenobarbitone in addition to the carbamazepine may have been important. Both compounds are powerful inducing agents of drug metabolism. In contrast to carbamazepine, phenytoin has been reported to inhibit AVP release. ${ }^{5}$ Reduction in the dose of carbamazepine led to a rapid resolution of the low sodium state, suggesting that this drug was the major causative factor. Inappropriate production of vasopressin may have contributed to the convulsions seen in this patient before admission. At one time water intoxication induced by vasopressin was suggested as a provocative test for epilepsy. Carbamazepine has shown its value in 